2017 , volume 6 , issue 3

Bojarenko, J. (2017). Variability of accounting policies - advantages and disadvantages. Copernican Journal of Finance \& Accounting, 6(3), 9-19. http://dx.doi.org/10.12775/CJFA.2017.013

\author{
JuLIJA Bojarenko* \\ Baltic International Academy
}

\title{
VARIABILITY OF ACCOUNTING POLICIES - ADVANTAGES AND DISADVANTAGES
}

Keywords: accounting policy, fixed assets, materiality criteria.

\section{J E L Classification: M41.}

Abstract: There are several provisions of accounting policy, which are not regulated by the legislation of the Republic of Latvia. As a result, companies are free to develop and adopt recognition criteria and the methods of evaluation and accounting for items of their financial statements.

This article deals with the choice of recognition criteria and the methods of evaluation of and accounting for fixed assets. The aim of the article is to develop recommendations on how to resolve the issue of accounting policy variabilities for the companies of the Republic of Latvia. The objects of the study are recognition criteria and the methods of evaluation and accounting of fixed assets. The recommendations on the solution of the issues related to variability of fixed asset accounting policy are based on the determination of materiality criteria.

\section{IIIINTRODUCTION}

Accounting policy is the key document, which regulates a company's accountancy. For the users of the company's financial statements, it ensures that business information is truthful, complete and comparable. Preparation of finan-

Date of submission: September 12, 2017; date of acceptance: December 26, 2017.

* Contact information: bojarenko@inbox.lv, Baltic International Academy, College of Accountancy and Finance, Lecturer, Lomonosova 4-222, Riga LV-1003, Latvia, phone: 37126759 426; ORCID ID: https://orcid.org/0000-0003-1300-7909. 
cial statements is regulated by the government. However, companies are free to choose recognition criteria as well as the methods of assessment and indication of items of the financial statements. The problem lies in determining the best option for recognition criteria and assessment and accountancy methods. Thus, it is essential to develop methodological approaches to the formation of companies' accounting policies in Latvia.

The aim of this article is to develop problem-solving suggestions related to the variability of fixed assets' accounting policy. To reach this aim the author analyses positive and negative aspects of variability of accounting policies at micro-level. The objects of this research are recognition criteria and methods applied for the evaluation and accounting of fixed assets.

\section{THE RESEARCH METHODOLOGY AND THE COURSE OF THE RESEARCH PROCESS}

Methodologically, the research is based on the application of scientific knowledge as well as on the basics of accounting theory and economic study.

Information background of the research is based on the laws and regulatory enactments of the Republic of Latvia applicable to accounting, as well as international financial accounting standards, studies of Latvian and foreign scientists, materials published in periodicals, scientific publications, in the Internet and legal reference systems.

The accounting requirements in the Republic of Latvia are regulated by the national legislation and by the regulations of the Cabinet of Ministers. The Law on Accounting is the fundamental law in accounting. To meet all the requirements of this law, the Cabinet of Ministers has issued Rule No 585 "Regulation Regarding the Conduct and Organisation of Accounting", which lists the documents that should be created and approved by each company. According to the previously mentioned Rule, accounting policy is one of the required documents, along with the book of accounts, inventory guidelines and other documents. However, the Rule also specifies the entities unaffected by the requirement to work out and adopt an accounting policy.

Accounting policy is a set of principles, methods, and regulations for accounting for the relevant economic transactions, facts, and events as well as assessment and indication of items of the financial statement. Latvian legislation deals with this concept of "accounting policy" in the Law on Annual Financial Statements and Consolidated Financial Statements, as well as in the Rules 
of the Cabinet of Ministers No 585 "Regulation Regarding the Conduct and Organisation of Accounting".

Accounting policy is an essential element, regulating the company's accounting to ensure truthfulness, completeness and comparability of business information. Besides, it is a major impact factor influencing key business figures and pricing policy of a company. When developing their own accounting policy, each company has a range of options in choosing recognition criteria and methods of assessment and indication of items of the financial statement.

For Latvian companies, the core of the problem is that the legislation does not regulate the content of several significant provisions of accounting policy. Below are just a few important issues, which, in accordance with the current legislation, are open to multiple-option solution:

- the unit of measure for recognition of non-material investments and fixed assets;

- methods of calculating depreciation on a certain category of fixed assets;

- materiality criterion of asset disposal value;

- methods of fixed assets accounting (cost model, revaluation model, etc.);

- evaluation of fixed assets according either to total cost or to direct production cost;

- criteria of recognizing bad debts;

- methods of assessment of bad debtors;

- criteria of estimating materiality of the prior period errors, etc.

All the issues listed above should be dealt with by each company and finalized in its accounting policy. This is where the problem arises, which the author has chosen as the subject matter of this study, namely, how to assess the outcome of freedom in the choice of recognition criteria and evaluation and accounting methods, which have a significant effect on the company's operating figures. The aim of this article is to develop recommendations to solve the problems related to variability of accounting policy at the companies of the Republic of Latvia. The object of this study are recognition criteria as well as the methods of fixed assets evaluation and accounting.

International expertise in the formation of accounting policy is reflected in the studies of Eldon S. Hendriksen, Michael F. Van Breda, Belverd E. Needles, Marian Powers, Susan V. Crosson (Principles of Accounting 12th edition, 2013) and many others. 
Many works written by scientists and experts deal with the development of accounting policies. Various aspects related to the formation of accounting policy have been covered in the works by:

- Latvian authors: Aivars Ludborzhs (Accounting for fixed assets, 2006), Inguna Leibus (Financial Accounting, 2016), etc.;

- Russian authors: N. P. Kondrakov (Accounting, 2013), A. D. Sheremet (Analysis and diagnostics of financial and economic activity of the enterprise: Textbook, 2009), etc.

All the authors emphasize the importance of making the right choice when adopting the accounting policy. However, so far, its impact on the company's financial indicators or business solutions has not been analysed in detail.

Many methodological issues have not been solved yet. This prevents the creation of a systemic integrated approach to the formation of the accounting policy that would meet the demands of market economy.

The Association of Accountants of the Republic of Latvia has worked in collaboration with the Ministry of Finance to create the set of guidelines for the management of accounting organisation documents, namely - "Guidelines on the Preparation of Accounting Organisation Documents". Accounting policy is among the documents described in the guidelines. The guidelines were developed to help companies produce adequate accounting documents and facilitate effective accounting and preparation of proper financial statements.

This study is intended for micro-companies and small companies. It is advisory rather than mandatory, since it is not a regulatory enactment. The study recommends some of the indicators of the variability of accounting policy. However, the methods of selecting such indicators are not dealt with (The Guidelines on the Preparation of Accountancy Documents, 2016).

\section{Selecting Fixed Assets Cost Criterion}

According to the legislation of the Republic of Latvia, each company is free to choose and specify its fixed assets cost criterion in its accounting policy (Cabinet of Ministers of the Republic of Latvia). Legislation does not provide any restrictions regarding the lowest or the highest value of this criterion. As a result, there are significant differences in companies' operating figures.

The choice of asset cost criterion impacts book value of fixed assets as well as cost value, which means that it affects the profit of the company. The choice 
of fixed assets cost criterion should meet certain qualitative characteristics of financial statements, such as reliability, carefulness, relevancy etc.

The "Guidelines on the Preparation of Accountancy Documents" drawn up by the Association of Accountants of the Republic of Latvia suggest that the amount of 200 Euro should be adopted as fixed assets cost criterion for microcompanies and small companies. However, criteria for micro-companies and small companies differ greatly, which can be seen in Table 1 representing the criteria of all the categories of companies in Latvia.

Table 1. Categories of companies according to the Law on the Annual Financial Statements and Consolidated Financial Statements

\begin{tabular}{|l|c|c|c|c|}
\hline \hline \multirow{2}{*}{\multicolumn{1}{c}{ Criteria }} & \multicolumn{3}{c|}{ Limit values } \\
\cline { 2 - 5 } & Micro-company & Small company & $\begin{array}{c}\text { Medium-sized } \\
\text { company }\end{array}$ & $\begin{array}{c}\text { Large } \\
\text { company }\end{array}$ \\
\hline \hline Balance sheet total, Euro & 350000 & 4000000 & 20000000 & 20000000 \\
\hline Net turnover, Euro & 700000 & 8000000 & 40000000 & 40000000 \\
\hline $\begin{array}{l}\text { Average number of employ- } \\
\text { ees during the financial year }\end{array}$ & 10 & 50 & 250 & 250 \\
\hline $\begin{array}{l}\text { Conditions at which criteria } \\
\text { are exceeded or not } \\
\text { exceeded }\end{array}$ & $\begin{array}{l}\text { At least two out of three criteria are not exceeded on the } \\
\text { balance sheet }\end{array}$ & $\begin{array}{l}\text { Exceeds two out } \\
\text { of three medium- } \\
\text { sized companies' } \\
\text { thresholds }\end{array}$ \\
\hline \hline
\end{tabular}

S o u r c e : own study based on: The Law on the Annual Financial Statements and Consolidated Financial Statements.

Accordingly, to ensure comparability of financial information, it is necessary to justify the choice of accounting policy.

The methodological choice of asset value criterion could be based on materiality criterion. Either annual average net book value of assets or gross assets could be used as the reference index for materiality criterion.

\section{Selecting the Method of Depreciation for the Certain Category of Fixed Assets}

According to local legislation, there are three methods of calculating depreciation of fixed assets, namely:

- straight line method;

- degression (accelerated) method; 
- methods depending on how heavily the asset is used (Cabinet of Ministers of the Republic of Latvia).

The choice of any of the above-mentioned methods is bound to affect the book value of assets and cost value, which, in its turn, will affect the profit.

A different method of calculating depreciation can be applied for each category of fixed assets. A category of fixed assets is a group of similar assets which are used by the company for similar purposes. Such categories are determined by companies at their own discretion.

However, local legislation does not provide any recommendations regarding the application of one or the other method for certain categories of fixed assets. Therefore, accounting policy of each company should prove the choice of the method of calculating depreciation on certain categories of fixed assets.

The methods applied for calculating depreciation on a certain category of assets should be based on the expected economic benefit resulting from the use of such assets during their service life. Straight line method corresponds with a forecast of a steady incoming of economic benefit or steady usefulness of the item in question. Degression (accelerated) method is in line with a forecast of a more intensive incoming of economic benefit during the first years of use and a less intensive one in subsequent years. However, methods refering to the intensity of use of a depreciable asset, are applicable in the cases where the incoming economic benefit is directly dependent on the intensity of wear and tear of the mentioned fixed asset in the company's economic activities.

Local companies tend to use straight line method for all categories of fixed assets, irrespective of distribution of the economic benefit during the wear and tear of this or that category of depreciable assets. The straight-line method is more often used because of its simplicity. However, this approach fails to provide adequate information about a company's financial status. Accounting policy should give reasons for the choice of the method applied for calculating depreciation, which should be based on the expected incoming economic benefit because of fixed asset utilization.

\section{SELECTING THE CRITERION For Disposal VALUe MATERIALITY}

According to the legislation of the Republic of Latvia, salvage value is an estimated amount that is expected to be received upon the sale of a fixed asset at the end of the recovery period, disposal charges deducted. Therefore, if the sal- 
vage value of a fixed asset is insignificant, it is not recognized when the asset's loss of value is recorded (Cabinet of Ministers of the Republic of Latvia).

Salvage value of a fixed asset affects calculation of depreciation, since it is involved in the calculation of depreciated value, which impacts net book value of assets as well as cost value. Consequently, profit is affected.

There are no guidelines in the regulatory enactments of the Republic of Latvia on how to determine materiality of salvage value of a fixed asset. Therefore, each company should determine materiality criteria at its own discretion and to reflect it in its accounting policy.

Purchase costs or production costs of a specific fixed asset item could be used as a reference index to determine the criterion of salvage value materiality.

The method of selecting the criterion of salvage value materiality could be based on the proportion of salvage value in the total purchase costs or production costs of this item of fixed assets.

\section{Evaluation of FiXed AsSETS According EITHER to Total Cost, INCLUDING Both DiRECT AND INDIRECT CoSTS, or to Direct Production Cost ONLY}

Approach to the evaluation of all the balance sheet items as well as profit and loss calculation is regulated by the Law on Annual Financial Statements and Consolidated Financial Statements. According this law, evaluation should be based on either purchase costs or production costs.

According to the national legislation:

- purchase costs comprise direct costs (purchasing price of goods or services) and additional (indirect) costs, related to the purchase;

- production costs comprise direct costs (costs related to the purchase of raw materials, basic materials and ancillaries, as well as other direct costs related to the production of the relevant item), and possible overhead/indirect costs, related to producing of the item (The law On the Annual Financial Statements and Consolidated Financial Statements, 2015).

Thus, in accordance with the legislation of the Republic of Latvia, it is up to the company to decide whether indirect costs should be included in the total cost of its fixed assets.

If indirect costs are included, fully or partly, in the production costs, this will result in the increase of fixed asset initial book value. It is only when de- 
preciation is calculated or the asset is written off, indirect costs will be shown in profit or loss statement and will result in a lower profit.

If, on the other hand, indirect costs are not included in the production costs, profit decrease will occur immediately, because they will be shown in profit or loss calculation of the year when they were incurred.

The method for the choice of asset evaluation according either to the total cost, including both direct and indirect costs, or to direct costs only, should be based on revenue and expenditure reconciliation by financial reference periods (The law On the Annual Financial Statements and Consolidated Financial Statements, 2015). All the costs, both direct and indirect, are related to the production of the fixed asset, which means that they will contribute to obtaining an economic benefit due to the use of the fixed asset.

However, if indirect costs are insignificant and cannot be divided among the assets that have been created, because such division would be too costly, it does not seem appropriate to increase asset value by their amount.

It would be worthwhile to use direct costs as the reference index for determining the materiality of indirect costs.

Methods determining indirect costs should be based on the proportion of indirect costs in the amount of total direct costs.

\section{Methods of AcCounting For FiXed AsSETS - Cost Model or Revaluation Model}

There are provisions in the legislation of Latvia allowing companies to apply revaluation model in the accounting for fixed assets if the true value of a fixed asset is significantly higher than its initial book value or its assessed value in the financial statement of the previous year, and if such increased value is expected to be long-lasting ().

Revaluation model can only be applied within the framework of the whole fixed asset group to which the asset in question belongs, in line with the accounting policy adopted by the company. A fixed asset group is a group of fixed assets of a similar nature and used by the company for similar purposes (Cabinet of Ministers of the Republic of Latvia).

The frequency of revaluation depends on the changes in the true value of fixed assets that are subject to revaluation:

- if the true value of the revaluated fixed asset differs significantly from its net book value, it should be revaluated further; 
- in the case of minor changes in the true value of a fixed asset, it can be revaluated once every three or every five years.

What are the criteria that would help us determine whether the difference between the true value and the net book value of a revaluated fixed asset is material or immaterial? Unfortunately, regulatory enactments of the Republic of Latvia do not provide an answer to this question. Therefore, the criterion for determining the materiality of the change in the true value, with the view of further revaluation of a fixed asset, should be developed in the accounting policy of each company.

The choice of revaluation method and subsequent regular revaluation should be based on the criterion of materiality, i.e. how much the true value of a fixed asset exceeds its initial book value or its assessed value shown in the previous year's financial statement.

Methodologically, the criterion for the materiality of the change in fixed asset true value could be based on the proportion of the change in the fixed asset true value in the total amount of its initial book value or its net book value at the end of the previous year.

\section{The Outcome of the Research Process and Conclusions}

Variability of accounting policy affects the key financial figures, such as total assets and the amount of profit.

When a company is developing its own accounting policy, it should ensure that it meets all the principles related to the drawing and disclosure of financial statements, namely, it should adhere to the proper characteristics of financial statements as well as the main conventions thereof (IAS 1 Presentation of Financial Statements, 1975).

Methodologically, the choice of criteria for materiality as well as the methods of accounting for and evaluation of fixed assets should be based on the truthfulness of financial information. When creating its accounting policy, each company should justify the choice of each particular option, since it affects:

- financial figures of the company's operation;

- financial status of the company;

- decisions made by the users of financial statements.

For example, the choice of an indicator of fixed asset accounting policy variability represented in this article could be based on the following indicators: 
- the criterion for fixed asset value can be chosen according either to the average annual net book value (e.g. from 0.5 to $1 \%$ ) or to gross assets (from 0.1 to $0.5 \%$ );

- the method for depreciation may be based on the expected incoming of economic benefit because of the use of a fixed asset throughout the entire recovery period. The straight line method is more appropriate for a constant incoming economic benefit; a more intensive incoming of economic benefits during the first years of use and a less intensive one in the subsequent years suggests the application of a degressive (accelerated) method. If the incoming of economic benefits depends directly on how intensively the asset goes through wear and tear, the methods relying on the intensity of asset utilization should be applied;

- materiality of fixed asset salvage value could be based either on its purchase value or on the production cost of the fixed asset, e.g. in an amount of $10 \%$ to $20 \%$;

- revaluation model for the assessment of fixed assets could be chosen according to the materiality of the change of fixed asset's real value as compared to its initial book value or its previous year's net book value, e.g. in an amount of $20 \%$ to $30 \%$.

A systematic and comprehensive approach to the formation and disclosure of fixed asset accounting policy will ensure the truthfulness of financial information.

On the one hand, the variability in fixed asset evaluation and accounting, as in the financial statements which are produced by companies in Latvia is incomparable. This may distort the results of the comparison of companies in terms of their efficiency and stability. On the other hand, a relative freedom in the choice of evaluation and accounting methods enable companies to adapt to specific market conditions, globally, nationally or in a micro environment. Accounting policy is a factor, which enhances companies' effectiveness and financial stability indicators.

The author of this article considers that in the context of the legislative freedom that companies in Latvia enjoy it is expedient to use the criteria of materiality in the choice of important issues in the process of formation of accounting policy. This will ensure the quality of financial information and its comparability. 


\section{REFERENCES}

Hendriksen, E. S., \& Breda, M. F. (2000). Accounting Theory (5th edition). McGraw-Hill Education.

IAS 1 Presentation of Financial Statements, http://www.ifrs.org/issued-standards/listof-standards/ias-1-presentation-of-financial-statements/ (accessed: 07.07.2017).

Kondrakov, N. P., \& Kondrakov, I. N. (2013). Accounting in charts and tables. Moscow: Prospect.

Kondrakov, N. P. (2013). Accounting: Textbook. Moscow: Scientific Publishing Center INFRA-M.

Leibus, I., Petersone, I., \& Jesemchik, A. (2016). Financial Accounting. Riga: Business Information Service.

Ludborzhs, A. (2006). Accounting for fixed assets. Riga: Business Information Service.

Needles, B. E., Powers, M., \& Crosson, S. V. (2013). Principles of Accounting, (12th edition). Cengage Learning.

Sheremet, A. D. (2009). Analysis and diagnostics of financial and economic activity of the enterprise: Textbook. Moscow: Scientific Publishing Center INFRA-M.

The Guidelines on the Preparation of Accountancy Documents, http://www.fm.gov.lv/ lv/sadalas/gramatvedibas_un_revizijas_politika/gramatvedibas_politika/gramatvedibas_organizacijas_dokumentu_rokasgramata_mikrosabiedribam_un_mazam_ sabiedribam_-_/ (accessed: 28.07.2017).

The Law on Accounting, https://likumi.lv/doc.php?id=66460 (accessed: 01.08.2017).

The law On the Annual Financial Statements and Consolidated Financial Statements, https://likumi.lv/ta/id/277779-gada-parskatu-un-konsolideto-gada-parskatu-likums (accessed: 21.07.2017).

The Rules of the Cabinet of Ministers No 585 "Regulation Regarding the Conduct and Organisation of Accounting", https://likumi.lv/doc.php?id=80418 (accessed: 01.08.2017). 